How to cite this article:

Rajput, A., Batool, S., \& Khan, F. A. (2020). Brand love among female consumers for fashion clothing. International Journal of Management Studies, 27(1), 1-19. https://doi.org/10.32890/ijms.27.1.2020.7379

\title{
BRAND LOVE AMONG FEMALE CONSUMERS FOR FASHION CLOTHING
}

\author{
*AMER RAJPUT \\ SABA BATOOL \\ FAHEEM AHMAD KHAN \\ Department of Management Sciences \\ COMSATS University Islamabad, Pakistan \\ *Corresponding author: amerrajput@gmail.com
}

\begin{abstract}
The purpose of this study is to investigate the association of brand anthropomorphism with anticipated separation distress through mediation of brand love among female consumers for fashion clothing brands. The conceptual research framework was empirically tested and data were collected through the questionnaire survey of 302 female consumers of fashion clothing brands in Pakistan. The structural equation modelling with partial least squares (SEM-PLS) is used to analyse the conceptual research framework. An explicit description is presented about the positive association of brand anthropomorphism with the anticipated separation distress through the mediation of brand love for 'fashion clothing among female consumers'. This study has empirically proven the positive association of brand anthropomorphism with the anticipated separation distress of brand love among female consumers for fashion clothing. Additionally, this study enhances the knowledge of brand love in the context of female consumers and managers of clothing brands.
\end{abstract}

Keywords: Anticipated separation distress, brand anthropomorphism, brand love, fashion clothing.

Received: 15/11/2019 Revised: 16/05/2020 Accepted: 17/05/2020 Published: 23/07/2020 


\section{Introduction}

Consumers are becoming fashion conscious and they keep themselves updated about the latest fashion trends of clothing brands. Consumers love branded fashion clothing because of the passionate emotional attachment with the brands. Female consumers are particularly keen to know the latest trends of fashion clothing because they want to dress elegantly. Female consumers love fashion clothing brands passionately (McNeill \& Venter, 2019). Fashion leadership behaviour is visible in female consumers for clothing brands and female consumers have a higher level of fashion leadership than men (H.-S. Kim \& Hong, 2011). Consumers differ in terms of their relationship with the brands (Kumar \& Kaushik, 2020); that relationship is love or hatred (Lin, $\mathrm{Xu}, \&$ Tao, 2020). The consumer brand relationship contains brand trust, commitment, perceived value, brand intimacy, and brand uniqueness (Carroll \& Ahuvia, 2006; Fournier, 1998). Firms engage in such marketing activities to improve the firms' performance (Nouri, Sanayei, Fathi, Kazemi, \& Soltani, 2016).

Brand anthropomorphism is an important predictor of brand love. The consumer brand relationship and addictive behaviour are attaining considerable attention to appearance related products such as fashion clothing brands (Mrad, Majdalani, Cui, \& El Khansa, 2020). Brand addictive behaviour can trigger anxiety if the brand disappears as well as it can cause anthropomorphic thinking (Batra, Ahuvia, \& Bagozzi, 2008). The consumer's emotional attachment can activate brand love (Junaid, Hou, Hussain, \& Kirmani, 2019). Separation distress is an important indicator of attachment (Zeifman, 2019); this can be applied in the context of female fashion clothing brand as such when there is a low probability of the brand to survive in the market. The loss of material possession "fashion clothing brand" is linked to feeling of sadness. A valuable aspect of brand love is the feeling of emotional bonding with the brand. The consumer feels anxiety when the loved brand disappears (Noel Albert \& Merunka, 2013). Consumer's strong desire to retain the loved brand can initiate separation distress (Thomson, MacInnis, \& Whan Park, 2005). Furthermore, consumer feels fear, anxiety, and apprehension when a brand seizes to exist (Batra et al., 2008).

Female fashion clothing brands are rapidly growing in Pakistan such as, Gul Ahmed, Sana Safinaz, Maria B, J., Alkaram, Khaadi, Nishat Linen, Warda, Limelight, Kayseria, and Bareeze (www.styleglow.com, 2020). Female consumers have several switching options for fashion 
clothing brands due to the availability of serval brands in the market at Pakistan. Female consumers fall in love with the latest fashion clothing brands. Female consumers have a passionate emotional attachment to such brands. Therefore, this study focuses the brand love among female consumers towards fashion clothing brands.

Brand love emerges when a consumer humanises the brand despite psychographic elements (Tan \& Lim, 2017). Consumers with the high need of belongingness tend to have more positive associations towards anthropomorphized brands. The consumer anthropomorphizes brands and this emotional bonding leads to brand love for fashion clothing brands. The consumer desires association with the brand and she can feel distress if brand ceases to exist and anthropomorphism can foster brand love (Rauschnabel \& Ahuvia, 2014). However, there is lack of empirical evidences that brand anthropomorphism is positively associated with the anticipated separation distress through mediation of brand love of female consumers in the context of fashion clothing brands. This study fills the knowledge gap by investigating the association of brand anthropomorphism with the anticipated separation distress through brand love among female consumers for fashion clothing brands. This study endeavours to answer such questions: Is brand anthropomorphism positively associated with brand love of female consumers in the context of fashion clothing brands? Is brand love positively associated with the anticipated separation distress of female consumers in the context of fashion clothing brands? Is brand anthropomorphism positively associated with the anticipated separation distress of female consumers in the context of fashion clothing brands? Is brand anthropomorphism positively associated with the anticipated separation distress through brand love mediation of female consumers in the context of fashion clothing brands?

\section{Literature Review}

\section{Brand Anthropomorphism}

Research on brand anthropomorphism has increased recently (Elena Delgado-Ballester, Palazón, \& Peláez, 2019). Anthropomorphism is a concept that comes from the word anthropos (human) and morfe (form); it is a cognitive process of human characteristics to non-human objects (Guthrie \& Guthrie, 1993). Anthropomorphism is defined as "the tendency to imbue the real or imagined behaviour of non-human 
agents with humanlike characteristics" (Epley, Waytz, \& Cacioppo, 2007). Instilling the characteristics of non-human agent with human like characteristics is often used in marketing communication to persuade consumers to perceive human characteristics of the brands.

Humans have strong ability to engage in anthropomorphic thinking (Shaman, Saide, \& Richert, 2018). Relational ties between the consumer and the brand are enhanced by anthropomorphism that is reflected in the context of brand love such as, the long-term relationship and emotional attachment. Sometimes consumers anthropomorphize with the brands to meet their social expectations (Epley et al., 2007; T. Kim, Sung, \& Moon, 2020). Anthropomorphic thinking enhances intimacy between consumer and the anthropomorphized brand (Hart, Jones, \& Royne, 2013).

Anthropomorphism influences female consumers more than the male (Wang, Baker, Wagner, \& Wakefield, 2007). Anthropomorphism makes the non-human brands familiar to consumers, decreases uncertainty and reassures the brands (Guthrie \& Guthrie, 1993). Humanised brands reduce uncertainty in ambiguous situations and give consumers the feeling of joy (Freling \& Forbes, 2005). Brand managers name the brands to favour anthropomorphism. Consumers perceive some brands as humans such as personal computers (Waytz et al., 2010), cars (Windhager et al., 2008) as well as non-human agents like supernatural entities (Landwehr, McGill, \& Herrmann, 2011). Anthropomorphic brands are perceived as humans and in external appearances, brands have similarity with the human physical attributes, for instance, packaging that resembles the human body (Landwehr et al., 2011).

\section{Brand Love}

The word 'love' is used for an object, activity and for a person. Brand love is an intense relationship between the consumer and a brand, just like interpersonal relationship (Biçakcığlu, İpek, \& Bayraktaroğlu, 2018). Satisfaction that turns into love results in the highest satisfaction. Consumer's love contains the characteristics of positive brand evaluation, brand passion, brand love's declaration, brand attachment and positive emotions (Noël Albert, Merunka, \& Valette-Florence, 2008). Brand love is a consumption related emotion in product usage situation (Richins, 1997). Love is prevalent in consumption behaviour, as it is the second most common emotion among all emotions (Schultz, Kleine, \& Kernan, 1989). Brand love 
is an attitude of the consumer to behave, feel, and think and this is also described as a satisfied consumer's emotional attachment (Aro, Suomi, \& Saraniemi, 2018). Brand love is a passion, attachment, positive evaluation of the brand and the declaration of love for the brand (Carroll \& Ahuvia, 2006).

Brand love positively affects brand loyalty, and that consumers are more committed to repurchase due to brand love (Aro et al., 2018). Additionally, brand love creates a state of dream for the consumers (Noël Albert et al., 2008). If someone criticises the loved brand, the consumer considers it as a personal insult and provides advocacy because the consumer considers the loved brand as one's self (Ahuvia, 2006). Accordingly, the consumer is ready to forgive and pay the premium price (Heinrich, 2009). Furthermore, brand love increases the consumer's willingness to invest more energy, time, and repurchase intention (Carroll \& Ahuvia, 2006).

\section{Anticipated Separation Distress}

Consumer has the emotional attachment to the brand during brand love (Thomson et al., 2005). Anticipated separation distress is an important indicator of attachment with a possibility for elimination of the brand love relationship if the brand ceases to exist in the market (Sajtos et al., 2020). Indeed, loss of material possession is linked to sadness. The emotional attachment with a brand is a valuable aspect of brand love. The consumer feels anxiety and apprehensive if the loved brand disappears from the market. The consumer feels a strong desire to keep and maintain closeness with the loved brand; even if there is a possibility of separation distress when she experiences being distance from the brand (Thomson et al., 2005). The consumer loves the brand due to its irreplaceability; thus, the consumer feels discomfort if the brand is lost. The consumer is willing to replace the brand with an equally desirable object. A strong brand attachment develops with the passage of time; this attachment develops interaction between an individual and attached object in the domain of brand commitment (Awan, Li, \& Haizhong, 2018).

\section{Conceptual Research Framework}

Anthropomorphism is the initial step to create brand love (Rauschnabel \& Ahuvia, 2014). It means anthropomorphic thinking helps to foster brand love (Huang, Zhou, Ye, \& Guo, 2020). Thus, 
the first hypothesis is postulated, $\mathrm{H}_{1}$ : Brand anthropomorphism is positively associated with brand love among female consumers for fashion clothing brands. Negative emotions drive controlled emotions. These extrinsic emotions are associated with switching behaviour that initiates separation distress. Consumers can be highly emotional reactive when they are afraid of separation of loved brands (Bowlby, 1980). Separation is painful just like fear and anxiety (Whan Park, MacInnis, Priester, Eisingerich, \& Iacobucci, 2010). There is lack of investigation about the consumer brand relationship that inquires the impact of separation distress on consumer behavior of the brands. Separation distress is an integral part of brand love (Batra et al., 2008). Consumer's separation distress level provides the indication of her brand attachment (Thomson et al., 2005). The anthropomorphised brand holds dedicated a long-term relationship despite the nonanthropomorphised brand (Chen, Wan, \& Levy, 2017). The consumer feels a personal loss in case of the brand disappearance from the market. Consumer's love towards an irreplaceable brand can cause anxiety if it is lost (Karanika \& Hogg, 2020). Therefore, the second hypothesis is postulated as $\mathrm{H}_{2}$ : Brand love is positively associated with the anticipated separation distress of female consumers for fashion clothing brands. Consumers establish a relationship with the brands in the same manner as humans develop the relationship with each other (Fournier, 1998). The consumer-brand relationship is considered credible if anthropomorphised brand is perceived as a loveable entity (Kervyn, Fiske, \& Malone, 2012). Anthropomorphism enhances the consumer-brand relationship and this can be reflected as separation distress. If the brand disappears from the market, the consumer will feel anxiety and discomfort (Kang, He, \& Shin, 2020); therefore, the third hypothesis is postulated as $\mathrm{H}_{3}$ : Brand anthropomorphism is positively associated with the anticipated separation distress of female consumers for fashion clothing brands. Consumers regard the brands as relationship partners (Rauschnabel \& Ahuvia, 2014) and anthropomorphism intensifies brand love. Given that the consumer desires to love the brand for a longer period of time; the disappearance of the loved brand can cause distress for the consumer (Rauschnabel \& Ahuvia, 2014). The consumer perceives the brand as a living object; thus this creates the feeling of association between the brand and the consumer (Bairrada, Coelho, \& Lizanets, 2019). Thus, the fourth hypothesis is stated as $\mathrm{H}_{4}$ : Brand anthropomorphism is positively associated with the anticipated separation distress through brand love among female consumers for fashion clothing brands. The conceptual research framework is shown in Figure 1. 


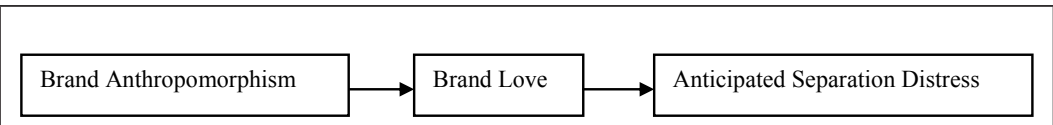

Figure 1. The conceptual research framework.

The conceptual model is based on the theory of anthropomorphism (Epley et al., 2007) and the theory of love (Sternberg, 1986). The theory of interpersonal love explains the relationship between the consumer and the brand (Noël Albert et al., 2008). This theory is based on intimacy (an emotional basis of love), passion (the motivational component) and commitment (the cognitive aspect). This theory is a triangular metaphor that conceptualises the interrelation among three fundamental components of intimacy, passion and commitment. The consumer perceives the brand as human according to the theory of anthropomorphism (Aaker, 1997).

\section{Methodology}

Self-administered questionnaire used to collect data to test the conceptual research framework (Diffley \& McCole, 2015). Sample sizes of 200 to 300 respondents provide an acceptable margin of error and fall before the point of diminishing returns as a rule (Ahmad \& Halim, 2017). Therefore, a target sample of 500 was decided due to a low response rate. Convenience sampling was used and sample size was 300. Questionnaires were distributed through emails to ten universities in the capital city of Islamabad in Pakistan for the selected female students who were consumers of fashion clothing brands. This resulted in 310 returned questionnaires with a response rate of 60.4 percent. Eight incomplete questionnaires were rejected. So, the eligible 302 responses were considered for data analysis with SmartPLS 3.

Brand anthropomorphism is measured by four items adopted from a previous study (Guido \& Peluso, 2015). Brand love is measured by using nine items of a previous study (Ahuvia, 2006). Anticipated separation distress is measured by four items adopted from a previous study (Whan Park et al., 2010). All items were rated using the 5-point Likert scale from strongly disagree $=1$ to strongly agree $=5$. 
IJMS 27(1), 1-19 (2020)

\section{Results}

Mostly respondents (69.3\%) belong to an age group of between 20 to 25 years and educational level depicts that approximately fifty-four percent $(54.1 \%)$ respondents are at the graduate level (Table 1$)$.

Table 1

Demographic Analysis of Female Respondents

\begin{tabular}{lcclcc}
\hline Age & Frequency & Percentage & Education & Frequency & Percentage \\
\hline $20-25$ & 210 & 69.3 & Matric & 8 & 2.6 \\
$26-30$ & 46 & 15.2 & Intermediate & 31 & 10.2 \\
$31-35$ & 33 & 10.9 & Bachelor & 164 & 54.1 \\
$36-40$ & 10 & 3.3 & Master & 41 & 13.5 \\
$41-45$ & 1 & 0.3 & MS/MPhil & 55 & 18.2 \\
45 and above & 3 & 1 & PhD & 4 & 1.3 \\
\hline
\end{tabular}

Cronbach's alpha is an indicator of reliability, all values are greater than .85. Composite reliability (CR) assesses the construct's consistency beyond the items of the variable (Joe F Hair, Sarstedt, Ringle, \& Mena, 2012). The internal consistency of reliability is obtained through $C R$. The $\mathrm{CR}$ values are greater than 0.70 to maintain internal consistency (Table 2; (Joseph F Hair, Black, Babin, Anderson, \& Tatham, 2006). The convergent validity is the extent to which measures correlate to the alternative measure of the same construct (Hair et al., 2006). The convergent validity is assessed by the value of AVE. The convergent validity is established as all the values are above 0.5 threshold value, see Table 2.

Discriminant validity is proven by the score of cross loading and criterion of Fornell and Larcker (1981). Square root of AVE value of brand anthropomorphism $=0.86$, brand love $=0.81$ and anticipated separation distress $=0.84$; all these values are higher than the inter construct correlation (Fornell \& Larcker, 1981) as shown in Table 3. The value of individual loading is greater than the respective loading (J. Hair, 2013). 
IJMS 27(1), 1-19 (2020)

Table 2

Construct Validity - Results of Outer Model

\begin{tabular}{|c|c|c|c|c|c|}
\hline Constructs & Items & $\begin{array}{l}\text { Factor } \\
\text { loadings }\end{array}$ & $\begin{array}{c}\text { Cronbach } \\
\text { alpha }\end{array}$ & $\mathrm{CR}$ & AVE \\
\hline \multirow{4}{*}{$\begin{array}{l}\text { Brand } \\
\text { Anthropomorphism }\end{array}$} & BA1 & .84 & .88 & .92 & .74 \\
\hline & BA2 & .88 & & & \\
\hline & BA3 & .86 & & & \\
\hline & BA4 & .85 & & & \\
\hline \multirow[t]{7}{*}{ Brand Love } & BL1 & .82 & .91 & .93 & .66 \\
\hline & BL2 & .81 & & & \\
\hline & BL3 & .80 & & & \\
\hline & BL5 & .77 & & & \\
\hline & BL6 & .81 & & & \\
\hline & BL8 & .83 & & & \\
\hline & BL9 & .81 & & & \\
\hline \multirow{4}{*}{$\begin{array}{l}\text { Anticipated } \\
\text { Separation Distress }\end{array}$} & ASD1 & .88 & .85 & .90 & .70 \\
\hline & ASD2 & .89 & & & \\
\hline & ASD3 & .86 & & & \\
\hline & ASD4 & .70 & & & \\
\hline
\end{tabular}

Note: CR: Composite Reliability; AVE: Average Variance Extracted; BA: brand anthropomorphism; BL: brand love; ASD: anticipated separation distress

Table 3

Discriminant Validity

\begin{tabular}{lllll}
\hline Sr. No. & Constructs & 1 & 2 & 3 \\
\hline 1 & Brand Anthropomorphism & $\mathbf{0 . 8 6}$ & & \\
2 & Brand Love & 0.51 & $\mathbf{0 . 8 1}$ & \\
3 & Anticipated Separation Distress & 0.42 & 0.66 & $\mathbf{0 . 8 4}$ \\
\hline
\end{tabular}

Brand anthropomorphism is positively associated with the brand love among female consumers for fashion clothing brands. The results 
support $\mathrm{H}_{1}$ as the value of path coefficient $=0.66$, $\mathrm{t}$-value $=20.37$, and $p$-value $=0.00$. Brand love is positively associated with the anticipated separation distress of female consumers for fashion clothing brands. The results support $\mathrm{H}_{2}$ as the value of path coefficient $=0.16$, $\mathrm{t}$-value $=$ 2.64 , $\mathrm{p}$-value $=0.00$. Brand anthropomorphism is positively associated with the anticipated separation distress of female consumers for fashion clothing brands. The results support $\mathrm{H}_{3}$ as the value of path coefficient $=0.40, \mathrm{t}$-value $=6.61, \mathrm{p}$-value $=0.00$, see Table 4 .

Table 4

Hypotheses Testing

\begin{tabular}{lcccc}
\hline Path & $\begin{array}{l}\text { Path } \\
\text { Coefficient }\end{array}$ & $\begin{array}{l}\text { T-Statistics } \\
(\mid \mathrm{O} /\end{array}$ & $\begin{array}{l}\mathrm{P} \\
\text { STDEVI })\end{array}$ & Value \\
\hline $\mathrm{H}_{1}: \begin{array}{l}\text { Brand anthropomorphism } \\
\rightarrow \text { Brand love }\end{array}$ & 0.66 & 20.37 & 0.00 & Supported \\
$\mathrm{H}_{2}: \begin{array}{l}\text { Brand love } \rightarrow \text { Anticipated } \\
\text { separation distress }\end{array}$ & 0.16 & 2.64 & 0.00 & Supported \\
$\mathrm{H}_{3}: \begin{array}{l}\text { Brand anthropomorphism } \\
\rightarrow \text { anticipated separation } \\
\text { distress }\end{array}$ & 0.40 & 6.61 & 0.00 & Supported \\
\hline
\end{tabular}

Brand anthropomorphism is positively associated with the anticipated separation distress through brand love of female consumers for fashion clothing brands. This is acknowledged to inspect the causal relationship between brand anthropomorphism and the anticipated separation distress by the addition of brand love as explanatory mediator (Munoz et al., 2016). Bootstrapping is applied in SmartPLS 3 for PLS-SEM to test the mediation. The first phase is to measure a direct effect of exogenous variable on endogenous variable, which should be significant if the mediator is not incorporated (Carrión, Nitzl, \& Roldán, 2017). When a direct relationship is significant in presence of a mediator then the path model measures indirect path significance in PLS (i.e. $\mathrm{p}^{12} * \mathrm{p}^{23}$ ). The basic requirement for this condition is the significance of individual path: $\mathrm{p}^{12}$ and $\mathrm{p}^{23}$. After running the bootstrapping, the indirect path can be evaluated and if the indirect path is significant then it means that the mediator variable absorbs direct path. The variance accounted for (VAF) is calculated as such: $\operatorname{VAF}=\left(\mathrm{p}^{12 *} \mathrm{p}^{23}\right) /\left(\mathrm{p}^{13}+\mathrm{p}^{12} * \mathrm{p}^{23}\right)$. According to J. Hair (2013), there are three conditions of mediation based on the VAF value such as, there is no mediation if $0<\mathrm{VAF}<0.20$; there is 
partial mediation if $0.20<\mathrm{VAF}<0.80$ and there is full mediation if the VAF $>0.80$. Brand love partially mediates the relationship between brand anthropomorphism and the anticipated separation distress. The VAF value indicates that twenty percent of the total effect of an exogenous variable brand anthropomorphism on the anticipated separation distress is explained by an indirect effect. Thus, the effect of brand anthropomorphism on the anticipated separation distress is partially mediated through brand love. The results support that brand anthropomorphism is positively associated with the anticipated separation distress through brand love among female consumers for fashion clothing brands as indicated in Table 5.

Table 5

Mediation Analyses: Brand Love as Mediator

\begin{tabular}{lcccccc}
\hline Path & $\begin{array}{c}\text { Direct } \\
\text { Effect }\end{array}$ & $\begin{array}{c}\text { Indirect } \\
\text { Effect }\end{array}$ & $\begin{array}{c}\text { Total } \\
\text { Effect }\end{array}$ & VAF & Mediation & Decision \\
\hline $\begin{array}{l}\text { Brand } \\
\text { anthropomorphism } \\
\rightarrow \text { anticipated }\end{array}$ & 0.40 & 0.10 & 0.51 & .20 & Partial & Supported \\
separation distress & & & & & & \\
$\begin{array}{l}\text { Brand } \\
\text { anthropomorphism } \\
\rightarrow \text { Brand love }\end{array}$ & 0.66 & & 0.66 & & & \\
$\begin{array}{l}\text { Brand love } \\
\rightarrow \text { anticipated }\end{array}$ & 0.16 & & 0.16 & & & \\
separation distress & & & & & & \\
\hline
\end{tabular}

\section{Assessment of $R^{2}$ and $Q^{2}$}

The structural model is assessed with the value of $R^{2}$ (coefficient of determination). The $R^{2}$ value confirms the model's precision with squared correlation between real and estimated values of endogenous variables. The exogenous variable is represented by the $R^{2}$ value of mutual effects on endogenous variables and this signifies the variance in endogenous constructs is defined with the total number of exogenous variables' association (Hair, 2013). The structural model has predictive relevance as the model reflects the $R^{2}=0.27$ and $R^{2}=$ 0.44 respectively (Table 6 ). The model's predictive relevance was used to cross validate for each endogenous variable with blindfolding test. The anticipated separation distress has $Q^{2}=0.18$ and brand love has $Q^{2}=0.26$. This shows a medium effect size. The PLS-SEM structural model' predictive relevance is established by both the $Q^{2}$ values $>0$ as reveal in Table 6. 
IJMS 27(1), 1-19 (2020)

Table 6

Results of $R^{2}$ and $Q^{2}$

\begin{tabular}{|c|c|c|c|c|}
\hline Endogenous Variable & $\mathrm{R}^{2}$ & Adj $R^{2}$ & $\begin{array}{l}\mathrm{Q}^{2}(1-\mathrm{SSE} / \\
\mathrm{SSO})\end{array}$ & Effects \\
\hline $\begin{array}{l}\text { Anticipated separation } \\
\text { distress }\end{array}$ & .27 & .26 & .18 & Medium \\
\hline Brand love & .44 & .43 & .26 & Medium \\
\hline
\end{tabular}

\section{Assessment of $f^{2}$}

The $f^{2}$ effect size measures the change in value of $R^{2}$ when exogenous variable is omitted from the model. The impact of a specific variable on endogenous variable is shown with $f$ effect size. In this study the $f$ effect size varies from small to large for all exogenous variables (Table 7).

Table 7

Results of $f^{2}$

\begin{tabular}{lcc}
\hline & $f^{2}$ & $\begin{array}{c}\text { Effect } \\
\text { Size }\end{array}$ \\
\hline $\begin{array}{l}\text { Brand anthropomorphism à Anticipated } \\
\text { separation distress }\end{array}$ & 0.12 & Small \\
Brand anthropomorphism à Brand love & 0.79 & Large \\
Brand love à Anticipated separation distress & 0.02 & Small \\
\hline $\begin{array}{l}\text { Small: } .0<f^{2} \text { effect size }<.15 ; \text { Medium: } .15<f^{2} \text { effect size }<.35 ; \text { Large: } f^{2} \text { effect size } \\
>.3\end{array}$
\end{tabular}

\section{Discussion}

This study empirically tests the association of brand anthropomorphism, brand love and the anticipated separation distress of female consumers for fashion clothing brands in Pakistan. Brand anthropomorphism is positively associated with brand love of female consumers for fashion clothing brands; this finding commemorates with the previous findings (E. Delgado-Ballester, Palazón, \& Pelaez-Muñoz, 2017; 
Rauschnabel \& Ahuvia, 2014). Female consumers fall in love with the fashion clothing brands due to the brand anthropomorphism. Brand love is positively associated with the anticipated separation distress of female consumers for fashion clothing brands. Female consumers of fashion clothing have the anticipated separation distress due to brand love. This finding commemorates with the previous findings (Chen et al., 2017; Hazan \& Zeifman, 1999; Thomson et al., 2005). This study has empirically proven that brand anthropomorphism is positively associated with the anticipated separation distress of female consumers for fashion clothing brands and this finding is in line with the previous findings (E. Delgado-Ballester et al., 2017; Hung \& $\mathrm{Lu}$, 2018). Brand anthropomorphism is positively associated with the anticipated separation distress through brand love among female consumers for fashion clothing brands. Brand love partially mediates between brand anthropomorphism and anticipated separation distress. This finding commemorates with the findings that are related to consumer-brand relationship (E. Delgado-Ballester et al., 2017; Rauschnabel \& Ahuvia, 2014).

\section{Managerial Implications}

Stimulating brand anthropomorphism provides greater opportunities to brand managers for facial expression to brand design, logo or celebrity endorsement. Marketing communication can play an important role to create the brand love. Marketers try to evoke brand love in the consumers' minds to initiate positive word of mouth. Brand managers must make sure to avoid anticipated separation distress among consumers when consumers are in love with the brands. Brand love needs to be considered one of the strategic imperatives to establish competitiveness. Brand love is not transaction specific; it is a nurtured relationship between the customer and the brand. Brand managers should use forms of anthropomorphism to make the product fascinating and memorable. This is suggested as a prime promotional strategy to develop brand love among female consumers for fashion clothing brands.

The limitations of the study provide future opportunities to academic researchers. The findings cannot be generalised because of the convenience sampling frame of female consumers of fashion clothing brands. Research into antecedents and outcomes of anthropomorphism is an emerging domain; therefore, future research can investigate several types of anthropomorphism, such as think, feel, emotional and divine. 


\section{Conclusion}

This study explains the relationship of brand anthropomorphism and brand love. This study describes that the relationship is stronger among the female consumers who have positive association towards brands. Brand anthropomorphism is the main predictor of brand love among female consumers for fashion clothing brands. Female consumers want to make a long-term relationship with loved brands and that the consumers feel separation distress when brands go out of existence in the market. The findings demonstrate that brand anthropomorphism is the pre-requisite of brand love for female consumers of fashion clothing brands. It is important for fashion clothing firms to understand the value of customer-brand relationship to cope with the competitive business environment. The customer-brand relationship is becoming a vital source of evaluating a firm's performance. The customer-brand relationship implies deep insights from the customers in order to create brand love. Brand anthropomorphism, brand love and anticipated separation distress are important factors to improve the brand performance of fashion clothing brands among the female consumers.

\section{Acknowledgements}

The authors gratefully acknowledge the use of service and facilities of digital library access provided by Higher Education Commission (HEC) Pakistan. This research received no specific grant from any funding agency in the public, commercial, or not-for-profit sectors.

\section{References}

Aaker, J. L. (1997). Dimensions of brand personality. Journal of Marketing Research, 34(3), 347-356.

Ahmad, H., \& Halim, H. (2017). Determining sample size for research activities. Selangor Business Review, 2(1), 20-34.

Ahuvia, A. (2006). I love it? Towards a unifying theory of love across diverse love objects. Retrieved from researchgate.net/ publication/30838734.

Albert, N., \& Merunka, D. (2013). The role of brand love in consumerbrand relationships. Journal of Consumer Marketing, 30(3), 258266. 
Albert, N., Merunka, D., \& Valette-Florence, P. (2008). When consumers love their brands: Exploring the concept and its dimensions. Journal of Business Research, 61(10), 1062-1075. doi:10.1016/j.jbusres.2007.09.014

Aro, K., Suomi, K., \& Saraniemi, S. (2018). Antecedents and consequences of destination brand love - A case study from Finnish Lapland. Tourism Management, 67(1), 71-81. doi:10.1016/j.tourman.2018.01.003

Awan, T. M., Li, X., \& Haizhong, W. (2018). Factors affecting employeebased brand equity: Evidence from China. International Journal of Management Studies, 24(2), 1-18.

Bairrada, C. M., Coelho, A., \& Lizanets, V. (2019). The impact of brand personality on consumer behavior: The role of brand love. Journal of Fashion Marketing and Management: An International Journal, 23(1), 30-47.

Batra, R., Ahuvia, A. C., \& Bagozzi, R. (2008). Brand love: Its nature and consequences. Michigan Dearborn University Ann Arbor, MI.

Biçakcıoğlu, N., İpek, İ., \& Bayraktaroğlu, G. (2018). Antecedents and outcomes of brand love: The mediating role of brand loyalty. Journal of Marketing Communications, 24(8), 863-877.

Bowlby, J. (1980). Attachment and loss: Loss (vol. 3). New York: Basic Books.

Carrión, G. C., Nitzl, C., \& Roldán, J. L. (2017). Mediation analyses in partial least squares structural equation modeling: Guidelines and empirical examples Partial Least Squares Path Modeling (pp. 173-195): Springer.

Carroll, B. A., \& Ahuvia, A. C. (2006). Some antecedents and outcomes of brand love. Marketing Letters, 17(2), 79-89. doi:10.1007/ s11002-006-4219-2

Chen, R. P., Wan, E. W., \& Levy, E. (2017). The effect of social exclusion on consumer preference for anthropomorphized brands. Journal of Consumer Psychology, 27(1), 23-34. doi:10.1016/j. jcps.2016.05.004

Delgado-Ballester, E., Palazón, M., \& Pelaez-Muñoz, J. (2017). This anthropomorphised brand is so loveable: The role of self-brand integration. Spanish Journal of Marketing - ESIC, 21(2), 89-101. doi:10.1016/j.sjme.2017.04.002

Delgado-Ballester, E., Palazón, M., \& Peláez, J. (2019). Anthropomorphized vs objectified brands: Which brand version is more loved? European Journal of Management and Business Economics. Vol. ahead-of-print No. ahead-of-print. https://doi.org/10.1108/EJMBE-04-2019-0063 
Diffley, S., \& McCole, P. (2015). Extending customer relationship management into a social context. The Service Industries Journal, 35(11-12), 591-610.

Epley, N., Waytz, A., \& Cacioppo, J. T. (2007). On seeing human: A three-factor theory of anthropomorphism. Psychological Review, 114(4), 864-886.

Fornell, C., \& Larcker, D. F. (1981). Structural equation models with unobservable variables and measurement error: Algebra and statistics. Journal of marketing research, 18(3), 382-388.

Fournier, S. (1998). Consumers and their brands: Developing relationship theory in consumer research. Journal of consumer research, 24(4), 343-373.

Freling, T. H., \& Forbes, L. P. (2005). An empirical analysis of the brand personality effect. Journal of Product \& Brand Management, 14(7), 404-413.

Guido, G., \& Peluso, A. M. (2015). Brand anthropomorphism: Conceptualization, measurement, and impact on brand personality and loyalty. Journal of Brand Management, 22(1), 1-19. doi:10.1057/bm.2014.40

Guthrie, S. E., \& Guthrie, S. (1993). Faces in the clouds: A new theory of religion: Oxford University Press on Demand.

Hair, J. (2013). Using the SmartPLS Software. Kennesaw State University. Powerpoint presentation/lecture.

Hair, J. F., Black, W. C., Babin, B. J., Anderson, R. E., \& Tatham, R. L. (2006). Multivariate data analysis (Vol. 6). Upper Saddle River, NJ: Pearson Prentice Hall.

Hair, J. F., Sarstedt, M., Ringle, C. M., \& Mena, J. A. (2012). An assessment of the use of partial least squares structural equation modeling in marketing research. Journal of the Academy of Marketing Science, 40(3), 414-433.

Hart, P. M., Jones, S. R., \& Royne, M. B. (2013). The human lens: How anthropomorphic reasoning varies by product complexity and enhances personal value. Journal of Marketing Management, 29(1-2), 105-121.

Hazan, C., \& Zeifman, D. (1999). Pair bonds as attachments. Handbook of attachment: Theory, research, and clinical applications: New York: Guilford Press.

Heinrich, D. (2009). All you need is love: Assessing consumers' brand love. In Proceedings of the American Marketing Association Summer Educators Conference, 15(2), 252-253. Chicago: American Marketing Association. 
Huang, R., Zhou, X., Ye, W., \& Guo, S. (2020). Think versus feel: Two dimensions of brand anthropomorphism. Journal of Product $\mathcal{E}$ Brand Management. Vol. ahead-of-print No. ahead-ofprint. https://doi.org/10.1108/JPBM-11-2018-2125

Hung, H.-Y., \& Lu, H.-T. (2018). The rosy side and the blue side of emotional brand attachment. Journal of Consumer Behaviour, 17(3), 302-312. doi:10.1002/cb.1712

Junaid, M., Hou, F., Hussain, K., \& Kirmani, A. A. (2019). Brand love: The emotional bridge between experience and engagement, generation-M perspective. Journal of Product $\mathcal{E}$ Brand Management, 28(2), 200-215. doi.org/10.1108/JPBM-04-20181852

Kang, I., He, X., \& Shin, M. M. (2020). Chinese consumers' herd consumption behavior related to Korean luxury cosmetics: The mediating role of fear of missing out. Frontiers in Psychology, 11(1), 1-13. doi: 10.3389/fpsyg.2020.00121.

Karanika, K., \& Hogg, M. K. (2020). Self-object relationships in consumers' spontaneous metaphors of anthropomorphism, zoomorphism, and dehumanization. Journal of Business Research, 109(1), 15-25. doi.org/10.1016/j.jbusres.2019.10.005

Kervyn, N., Fiske, S. T., \& Malone, C. (2012). Brands as intentional agents framework: How perceived intentions and ability can map brand perception. Journal of Consumer Psychology, 22(2), 166-176.

Kim, H.-S., \& Hong, H. (2011). Fashion leadership and hedonic shopping motivations of female consumers. Clothing and Textiles Research Journal, 29(4), 314-330.

Kim, T., Sung, Y., \& Moon, J. H. (2020). Effects of brand anthropomorphism on consumer-brand relationships on social networking site fan page: The mediating role of Social Presence. Telematics and Informatics, 51, 101406. doi.org/10.1016/j. tele.2020.101406

Kumar, V., \& Kaushik, A. K. (2020). Building consumer-brand relationships through brand experience and brand identification. Journal of Strategic Marketing, 28(1), 39-59.

Landwehr, J. R., McGill, A. L., \& Herrmann, A. (2011). It's got the look: The effect of friendly and aggressive "facial" expressions on product liking and sales. Journal of Marketing, 75(3), 132-146.

Lin, L., Xu, Y., \& Tao, Q. (2020). Motivational drivers of Chinese consumers' brand avoidance behaviours: A perspective of sportswear. International Journal of Fashion Design, Technology and Education, 13(1), 45-57. 
McNeill, L., \& Venter, B. (2019). Identity, self-concept and young women's engagement with collaborative, sustainable fashion consumption models. International Journal of Consumer Studies, 43(4), 368-378.

Mrad, M., Majdalani, J., Cui, C. C., \& El Khansa, Z. (2020). Brand addiction in the contexts of luxury and fast-fashion brands. Journal of Retailing and Consumer Services, 55, 102089. doi. org/10.1016/j.jretconser.2020.102089

Munoz, R. T., Hoppes, S., Hellman, C. M., Brunk, K. L., Bragg, J. E., \& Cummins, C. (2018). The effects of mindfulness meditation on hope and stress. Research on Social Work Practice, 28(6), 696-707.

Nouri, B. A., Sanayei, A., Fathi, S., Kazemi, A., \& Soltani, M. (2016). Designing a model for the relationship between marketing activities and organization performance: Meta-analysis on the moderating role of research topic characteristics. International Journal of Management Studies, 23(2), 1-26.

Rauschnabel, P. A., \& Ahuvia, A. C. (2014). You're so lovable: Anthropomorphism and brand love. Journal of Brand Management, 21(5), 372-395. doi:10.1057/bm.2014.14

Richins, M. L. (1997). Measuring emotions in the consumption experience. Journal of Consumer Research, 24(2), 127-146.

Sajtos, L., Cao, J. T., Espinosa, J. A., Phau, I., Rossi, P., Sung, B., \& Voyer, B. (2020). Brand love: Corroborating evidence across four continents. Journal of Business Research. doi.org/10.1016/j. jbusres.2020.02.040

Schultz, S. E., Kleine, R. E., \& Kernan, J. B. (1989). These are a few of my favorite things: Toward an explication of attachment as a consumer behavior construct. Advances in Consumer Research, 16(1), 359-366.

Shaman, N. J., Saide, A. R., \& Richert, R. A. (2018). Dimensional structure of and variation in anthropomorphic concepts of god. Frontiers in Psychology, 9, 1425. doi: 10.3389/fpsyg.2018.01425

Sternberg, R. J. (1986). A triangular theory of love. Psychological Review, 93(2), 119-135.

Tan, S. S., \& Lim, C. C. (2017). A preliminary study on the relationship between psycho graphic factors and the purchase of life insurance. International Journal of Management Studies, 21(1), $1-22$. 
Thomson, M., MacInnis, D. J., \& Whan Park, C. (2005). The ties that bind: Measuring the strength of consumers' emotional attachments to brands. Journal of Consumer Psychology, 15(1), 77-91.

Wang, L. C., Baker, J., Wagner, J. A., \& Wakefield, K. (2007). Can a retail web site be social? Journal of Marketing, 71(3), 143-157.

Waytz, A., Morewedge, C. K., Epley, N., Monteleone, G., Gao, J.-H., \& Cacioppo, J. T. (2010). Making sense by making sentient: Effectance motivation increases anthropomorphism. Journal of Personality and Social Psychology, 99(3), 410-435.

Whan Park, C., MacInnis, D. J., Priester, J., Eisingerich, A. B., \& Iacobucci, D. (2010). Brand attachment and brand attitude strength: Conceptual and empirical differentiation of two critical brand equity drivers. Journal of Marketing, 74(6), 1-17.

Windhager, S., Slice, D. E., Schaefer, K., Oberzaucher, E., Thorstensen, T., \& Grammer, K. (2008). Face to face. Human Nature, 19(4), 331-346.

www.styleglow.com. (2020). Best Clothing Brands in Pakistan 2020.

Zeifman, D. M. (2019). Attachment theory grows up: A developmental approach to pair bonds. Current Opinion in Psychology, 25, 139143. doi.org/10.1016/j.copsyc.2018.06.001 